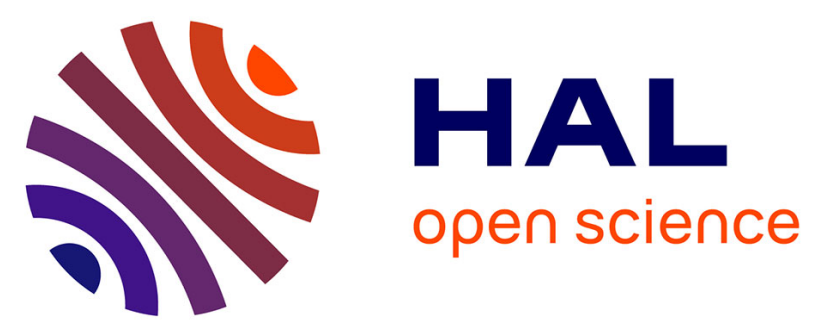

\title{
Geology and morphostructural evolution of Piton de la Fournaise
}

Laurent Michon, Jean-François Lénat, Patrick Bachèlery, Andrea Di Muro

\section{To cite this version:}

Laurent Michon, Jean-François Lénat, Patrick Bachèlery, Andrea Di Muro. Geology and morphostructural evolution of Piton de la Fournaise. Bachelery, Patrick and Lénat, Jean-François and Di Muro, Andrea and Michon, Laurent. Active Volcanoes of the Southwest Indian Ocean: Piton de la Fournaise and Karthala, Springer, pp.45-59, 2016, Active volcanoes of the World, 978-3-642-31394-3. 10.1007/978-3-642-31395-0_4 . hal-01147341

\section{HAL Id: hal-01147341 \\ https://hal.science/hal-01147341}

Submitted on 24 Oct 2016

HAL is a multi-disciplinary open access archive for the deposit and dissemination of scientific research documents, whether they are published or not. The documents may come from teaching and research institutions in France or abroad, or from public or private research centers.
L'archive ouverte pluridisciplinaire HAL, est destinée au dépôt et à la diffusion de documents scientifiques de niveau recherche, publiés ou non, émanant des établissements d'enseignement et de recherche français ou étrangers, des laboratoires publics ou privés. 


\title{
Geology and Morphostructural Evolution of Piton de la Fournaise
}

\author{
Laurent Michon, Jean-François Lénat, Patrick Bachèlery \\ and Andrea Di Muro
}

\begin{abstract}
The morphology of Piton de la Fournaise volcano results from the succession of construction, destruction and deformation processes that occurred since at least $530 \mathrm{ka}$. The chaotic surface of the gently dipping submarine flanks indicates that volcaniclastic deposits related to massive flank landslides and erosion cover most of the submarine flanks. Only a few seamounts like Cône Elianne and the submarine continuation of the rift zones are built by lava flows. In the subaerial domain, Piton de la Fournaise exhibits deeply incised canyons evidencing intense erosion and eastward verging scarps whose origin is still controversial. The different interpretations invoking flank landslides and/or summit collapse calderas are summarized. Geological data indicate a twofold construction of Piton de la Fournaise. Between 530 and 60 kyrs, the volcanic centre located in the current Plaine des Sables led to the building of the western part of the massif. The volcanic centre migrated eastwards to its current location, possibly at 60-40 kyrs. Then Piton de la Fournaise experienced caldera collapses and recurrent phreatomagmatic eruptions especially between
\end{abstract}

L. Michon (凶)

Laboratoire Géosciences Réunion, Institut de Physique du Globe de Paris, Université de La Réunion, Sorbonne Paris Cité, CNRS, F-97744 Saint Denis, France e-mail: laurent.michon@univ-reunion.fr

J.-F. Lénat · P. Bachèlery

Laboratoire Magmas et Volcans, UMR CNRS-IRD

6524, Observatoire de Physique du Globe de Clermont-Ferrand, Université Blaise Pascal, F-63038 Clermont-Ferrand, France
A. Di Muro
Institut de Physique du Globe de Paris, Observatoire
Volcanologique du Piton de la Fournaise (OVPF),
Sorbonne Paris Cité, UMR 7154 CNRS,
Université Paris Diderot, 75005 Paris, France 
4880 and $2340 \mathrm{yr}$ BP as evidenced by the Bellecombe ash deposit. Most of the recent volcanic activity is now currently focused restricted inside the Enclos Fouqué caldera where lava flow accumulation and rare explosive events built the 400-m-high Central Cone.

\subsection{Introduction}

The morphology of volcanoes results from construction, destruction and deformation processes that interact during their evolution (e.g., Moore 1964; Moore and Mark 1992; Merle and Borgia 1996; Rowland and Garbeil 2000). Thus the analysis of the morphology allows the identification of structures whose development is related to internal processes and/or to a specific eruption history (e.g., Tort and Finizola 2005). At Piton de la Fournaise, the succession of construction and dismantling phases (i.e., erosion and landslide) led to the development of a complex morphology (e.g., Bachèlery 1981; Rowland and Garbeil 2000). One of the most striking features is the E-W elongated horseshoe-shaped structure in which the currently active Central Cone developed (Fig. 4.1). This structure is composed, from west to east, by the Enclos Fouqué depression, the Grandes Pentes (upper volcano flank), and the Grand Brûlé (lower volcano flank) and is bounded by 100 - to 200 -m-high subvertical escarpments, the Bois Blanc, Bellecombe and Tremblet cliffs in the north, west and south, respectively. The formation of the U-shaped structure is one the greatest scientific controversies on Piton de la Fournaise. Thus, the present study aims at
Fig. 4.1 Morphology of the volcanic edifice of $\mathrm{La}$ Réunion. Shaded bathymetric map compiled from FOREVER and ERODER oceanic surveys. The submarine flanks are characterized by slopes $<5^{\circ}$ on average

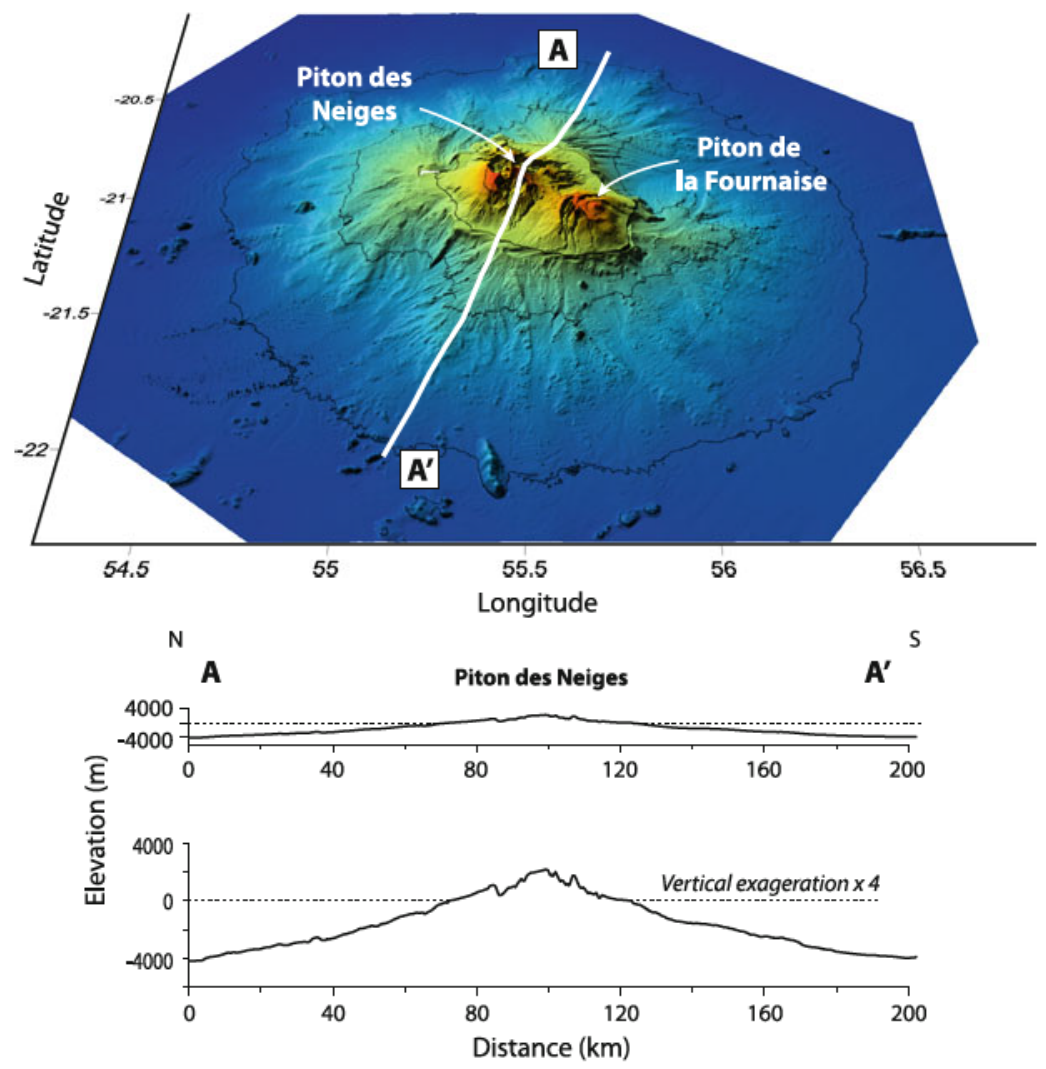


describing the submarine and subaerial morphologies of Piton de la Fournaise and to present the different interpretations, which have been published to explain the development of the main volcano-tectonic structures.

\subsection{Morphology}

The whole volcanic complex of La Réunion is a large cone of about $51,500 \mathrm{~km}^{3}$, from the sea floor (about $4200 \mathrm{~m}$ below sea level) to the summit of the dormant Piton des Neiges volcano (3070 $\mathrm{m}$ above sea level). The morphology of the very large submarine base (volcano diameter of about $210 \mathrm{~km}$ ) is well known since the FOREVER and ERODER oceanographic cruises in 2006 (Fig. 4.1; Saint-Ange et al. 2011, 2013; Le Friant et al. 2011; Sisavath et al. 2011, 2012; Babonneau et al. 2013). Submarine flanks have relatively gentle slopes ranging between $2^{\circ}$ and $5^{\circ}$ on average (Fig. 4.1; Saint-Ange et al. 2011; Lénat, Chap. 3). This morphology of the submarine slopes of La Réunion clearly differs with that observed in Hawaii (Big Island and Lo'ihi for instance), where the submarine flanks are much steeper than those of La Réunion (10 to 15; Malahoff 1987; Bachèlery and Villeneuve 2013). In Hawaii, the slopes are widely constructed by lava-flows, mainly along the rift zones, and the destabilization products are restricted to well-defined structures. Conversely, in La Réunion, products of flank destabilization and erosion are widely distributed on the submarine slopes (Gailler and Lénat 2010; Saint-Ange et al. 2013). These deposits are related to slow deformation (spreading) and rapid mass movements (debris avalanches, or sediment transfer by shallow landsliding and turbidity currents; Oehler et al. 2008; Le Friant et al. 2011). Only a few portions of the submarine flanks of Piton de la Fournaise are directly built by lava-flows. The importance of remobilization processes on La Réunion island results in a widespread extension of volcaniclastic products (Babonneau et al. 2016, Chap. 6) and a very wide submarine base of the volcanic edifice compared to the size of the island itself; the subaerial part of the edifice representing only $4 \%$ of the total volume.

Among volcaniclastic deposits, large volume of debris avalanche deposits (Fig. 4.2; Oehler et al. 2004; Lénat et al. 2009; Le Friant et al. 2011; Saint-Ange et al. 2013) have been identified on the submarine flanks of Piton de la Fournaise. They have been identified from their chaotic morphology, acoustic facies on backscatter imagery, seismic reflexion profiles, deep-water pictures and dredging. These deposits reveal the occurrence of old large flank collapse events Piton de la Fournaise. Some K/Ar ages of subaerial lava flows dredged on the submarine east flank of Piton de la Fournaise (Lénat et al. 2009) suggest a main flank landslide about 40-60 ka, which could be correlated with the development of the Plaine des Sables scarp (Oehler et al. 2008).

Submarine debris avalanche deposits are cut by several canyons and depressions, like Chenal Vincent, edged with abrupt walls (Fig. 4.2). In the valley floors of these depressions, the volcaniclastic sedimentation testifies to sedimentary processes that are mainly dominated by erosion and sediment transport due to coastal and submarine gravity instabilities (Cochonat et al. 1990; Ollier et al. 1998; Saint-Ange et al. 2013; Babonneau et al. 2016, Chap. 6). Furrows, scours, sediment waves, current ripples and a wide range of gravity flows are identified, suggesting a high sediment supply. South of Piton de la Fournaise, in the continuation of the Rivière des Remparts and Rivière Langevin (Fig. 4.2), recurrent gravity events and efficient (fast?) sediment transfer related to flash floods result into turbidity currents incising progressively deeper submarine canyons across the upper slope and forming deep-sea fans composed by turbidite deposits (see Babonneau et al. 2016, Chap. 6 and references herein).

As previously indicated, the portions of the submarine flanks built by lava-flows accumulations are fairly rare. They essentially correspond to the submarine extensions of the subaerial NE and SE rift zones (Fig. 4.2). The smooth surface that characterizes the shallowest part (from sea 


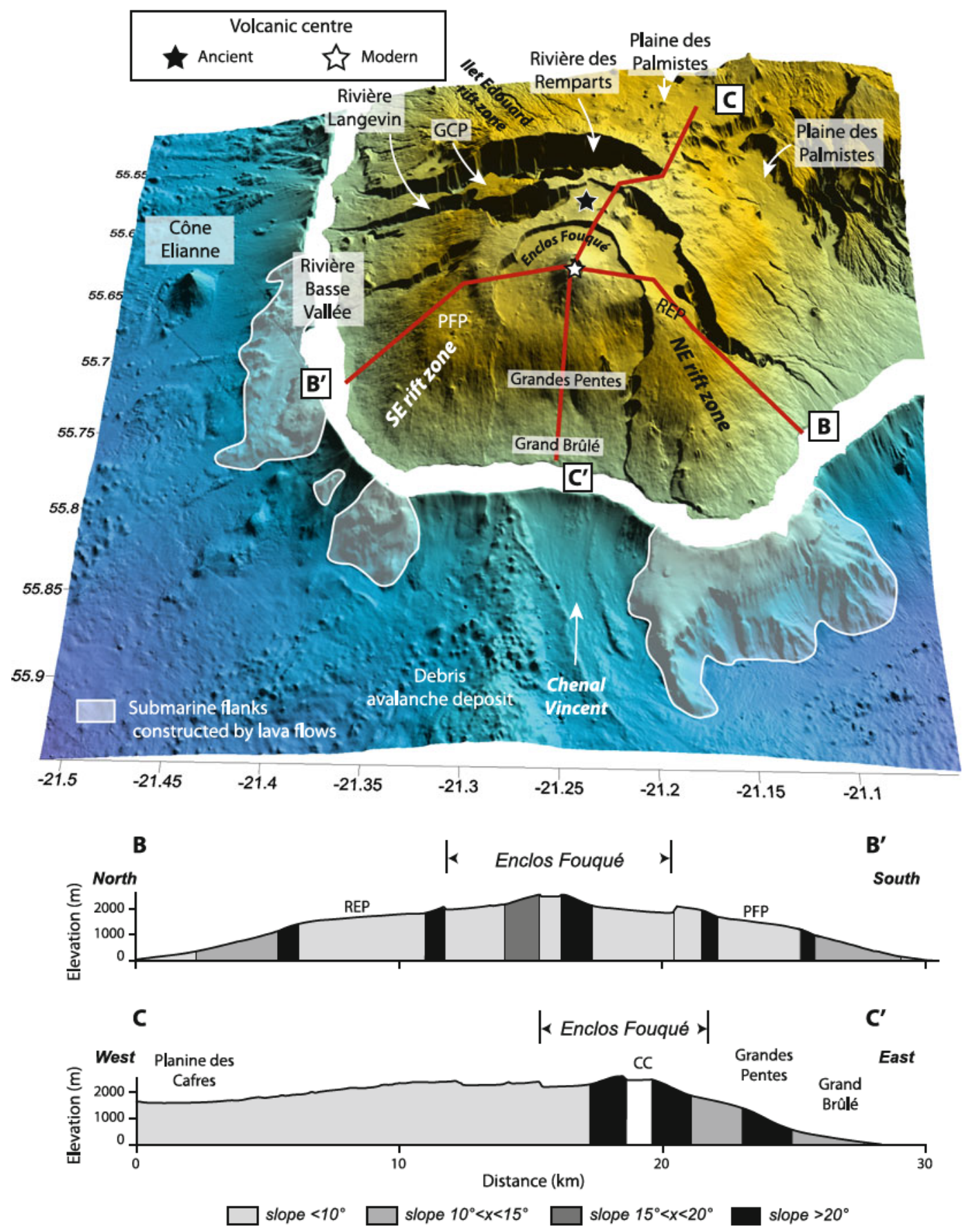

Fig. 4.2 Morphology of Piton de la Fournaise volcano. Subaerial (black) and submarine (white) contour lines every $200 \mathrm{~m}$. The subaerial part of the edifice shows a “overturned soup plate" geometry. CC Central Cone. PFP Piton de Fourche plateau. REP Rivière de l'Est plateau 
level to $1800 \mathrm{~m}$ deep) of the NE rift zone submarine extension is in a good morphologic continuity with the subaerial slopes. However, the incision of deepest relief together with two datings at $3.34 \pm 0.07$ and $3.77 \pm 0.08 \mathrm{Ma}$ obtained on pillow lavas dredged 1400 and $2100 \mathrm{~m}$ depth on this area (Smietana 2011) clearly indicate that the NE rift zone is built on an older edifice, probably Les Alizés volcano (Lénat et al. 2001a; Lénat, Chap. 3).

In addition, several large volcanic cones have been identified between 1500 and $2500 \mathrm{~m}$ below sea level. Cône Elianne, on the south submarine flank, stands out because of its height (about $700 \mathrm{~m}$; Fig. 4.2). In comparison with the today's summit cone of Piton de la Fournaise volcano, Cône Elianne is twice larger. TOBI acoustic imagery allows to clearly identified lava flows on the southern flank of this cone (Fig. 4.3). Thus, Cône Elianne was probably built by the accumulation of several eruptive phases. Samples of alkali basalt, with a Th-U age estimated between
70 and $105 \mathrm{ka}$, were dredged on the western flank of this cone during the FOURNAISE 2 cruise (Lénat et al. 2009). Smietana (2011) obtained a K-Ar age of $127 \pm 8 \mathrm{ka}$ on the same sample.

In the subaerial domain, Piton de la Fournaise reaches a maximum elevation of $2630 \mathrm{~m}$ above sea level at the summit of the Central Cone that built in the Enclos Fouqué caldera (Fig. 4.2). The massif is characterized by three main morphological features (Fig. 4.2): (1) The flanks, which are continuous from the summit to the sea in the North, in the East and in the South, whereas the western flank is buttressed by the Piton des Neiges edifice (2), very deeply incised valleys, which dissect the western oldest part of the edifice and (3) two asymmetric caldera cliffs, the Plaine des Sables caldera and the Enclos Fouqué caldera, bounded by up to 100 -m-high escarpments (Michon and Saint-Ange 2008; Lénat et al. 2012).

The flanks of Piton de la Fournaise are characterized by distinct slope domains, from the
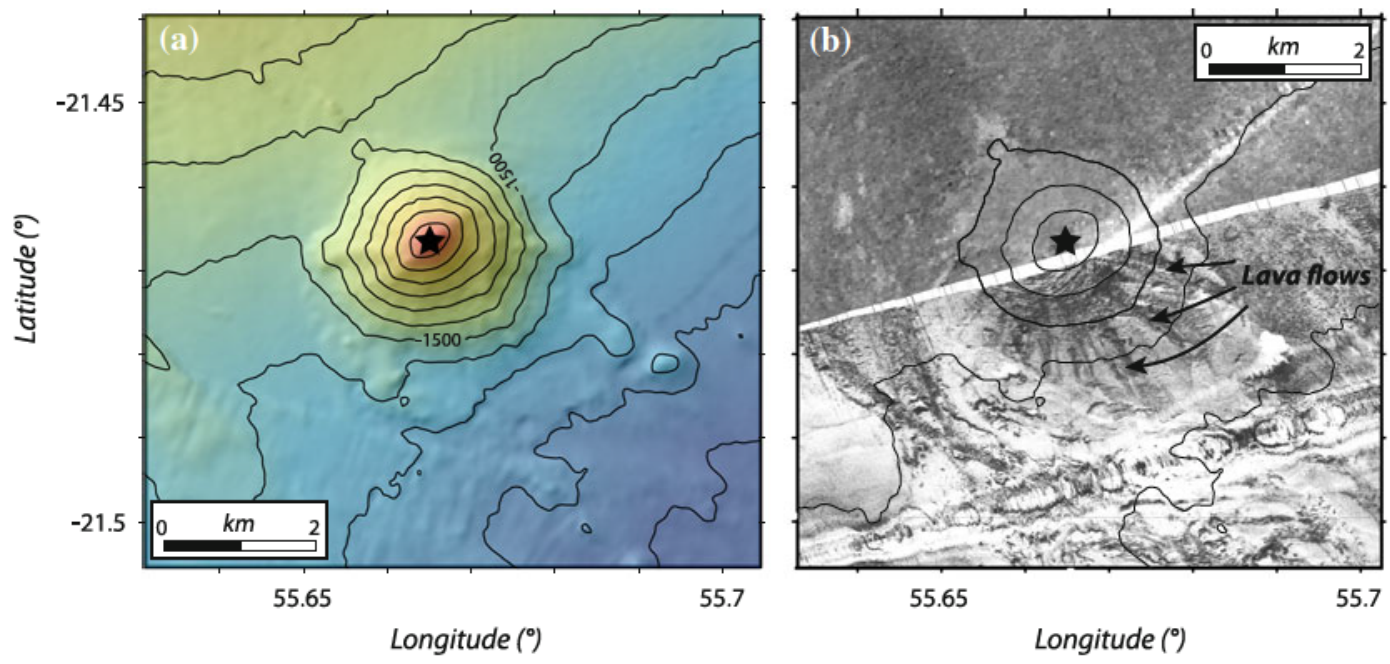

Fig. 4.3 Cône Elianne on the southern submarine flank of Piton de la Fournaise (see Fig. 4.2 for location). a Shaded bathymetry from ERODER1 oceanic survey. Contour lines every $100 \mathrm{~m}$. b Backscatter acoustic imagery from ERODER1 survey (upper part) and TOBI side-scan sonar (lower part-ERODER3 data). Representation of TOBI images on the backscatter map requires the inversion of their reflectivity scale. High reflectivity facies (black) are assumed to be formed by more heterogeneous coarse products than those shown by low reflectivity (white). Cône Elianne's summit reaches the depth of $800 \mathrm{~m}$ bsl and its base diameter is approximately $3000 \mathrm{~m}$. Chaotic lava flows are clearly visible on the TOBI acoustic imagery. Pillow-lavas dated at $127 \pm 8 \mathrm{ka}$ (see text) were dredged on the northern flank of Cône Elianne during the FOURNAISE 2 cruise (Lénat et al. 2009). Contour lines every $200 \mathrm{~m}$ 
coast to the summit (Fig. 4.2; Rowland and Garbeil 2000; Michon and Saint-Ange 2008). At low elevations, the slope value range between $8^{\circ}$ and $15^{\circ}$, corresponding to typical values for subaerial slopes of basaltic oceanic volcanoes (Mark and Moore 1987; Hürlimann et al. 2004). At higher elevations, the topography of the southern, eastern and northern flanks is characterized by steep slope zones ranging between $20^{\circ}$ and $35^{\circ}$, while the summit shows slopes between $2^{\circ}$ and $8^{\circ}$, if the escarpments and the active cone are disregarded. Such a slope distribution is strikingly similar to what is observed on Fernandina, Wolf, and Cerro Azul volcanoes in the western Galapagos archipelago (Rowland 1996; Rowland and Garbeil 2000) and remarkably differ from Hawaiian volcanoes where subaerial slopes do not exceed $15^{\circ}$ (Bachèlery and Villeneuve 2013). In contrast, this slope distribution is not observed on the western flank of Piton de la Fournaise where the edifice is buttressed by Piton des Neiges (Fig. 4.2). The resulting morphology is characterized by a geometry resembling an "overturned soup plate".

The western part of Piton de la Fournaise is cut by deep valleys that incised the oldest parts of the volcano. The Rivière des Remparts, Rivière Langevin, Rivière de l'Est and Rivière Basse Vallée have been sculptured by a complex interaction of erosion, volcanism and tectonics (Merle et al. 2010). As frequently observed in La Réunion, the valleys become wider upstream. They are bounded by steep walls, which experience repeated collapses yielding an upstream recession. The destabilization products are subsequently transported by torrential river, which floods in during tropical cyclones (Garcin et al. 2005; Saint-Ange et al. 2011). Plaine des Palmistes, in the northwest flank of Piton de la Fournaise, is a complex and wide area, with a depression open to the sea edged by steep scarps and partially filled in by young lava flows. The current morphology of Plaine des Palmistes reveals the prevalence of erosion in its shaping.

\subsection{Volcano-Tectonic Structures}

\subsubsection{Collapse Structures}

Several collapse-related structures can be identified in the morphology of Piton de la Fournaise massif. All of them have been interpreted either as the scar of huge landslides or the scarps of collapse calderas (Bachèlery 1981; Chevallier and Bachèlery 1981; Duffield et al. 1982; Lénat et al. 1989; Labazuy 1996; Merle and Lénat 2003; Oehler et al. 2004, 2008; Michon and Saint-Ange 2008). The youngest one corresponds to the poly-lobate Enclos Fouqué caldera, which is opened in the east and connected to the Grand Brûlé depression (Fig. 4.4). The U-shaped structure of the eastern flank is bounded by the Tremblet and Bois Blanc scarps in the South and the North, respectively. The horseshoe-shaped geometry was interpreted as the result of a huge flank landslide (Fig. 4.4a; Duffield et al. 1982; Lénat et al. 1989; Labazuy 1996; Oehler et al. 2004, 2008). This interpretation contrasts with the pioneer one of Bachèlery (1981) in which the Enclos Fouqué caldera results from coalescent caldera collapses and the Grandes Pentes correspond to the head of an eastwards directed flank landslide (Fig. 4.4b). Two additional interpretations invoking a causal relationship between the Grand Brûlé/Grandes Pentes and the Enclos Fouqué caldera were more recently proposed (Merle and Lénat 2003; Michon and Saint-Ange 2008). In both models the Enclos Fouqué caldera is interpreted as an hydrothermal collapse caldera triggered by the lateral deformation of the hydrothermal system caused by the landslide (Fig. 4.4c; Merle and Lénat 2003) or the vertical collapse (Fig. 4.4d; Michon and Saint-Ange 2008) of the Grand Brûlé.

Another larger structure, the Plaine des Sables limited by a north-south trending scarp, is well developed west of the Enclos Fouqué (Fig. 4.5). This structure would result from a vertical collapse of the edifice (Fig. 4.5a; Bachèlery 1981), a large flank landslide toward the east (Fig. 4.5b, c; 

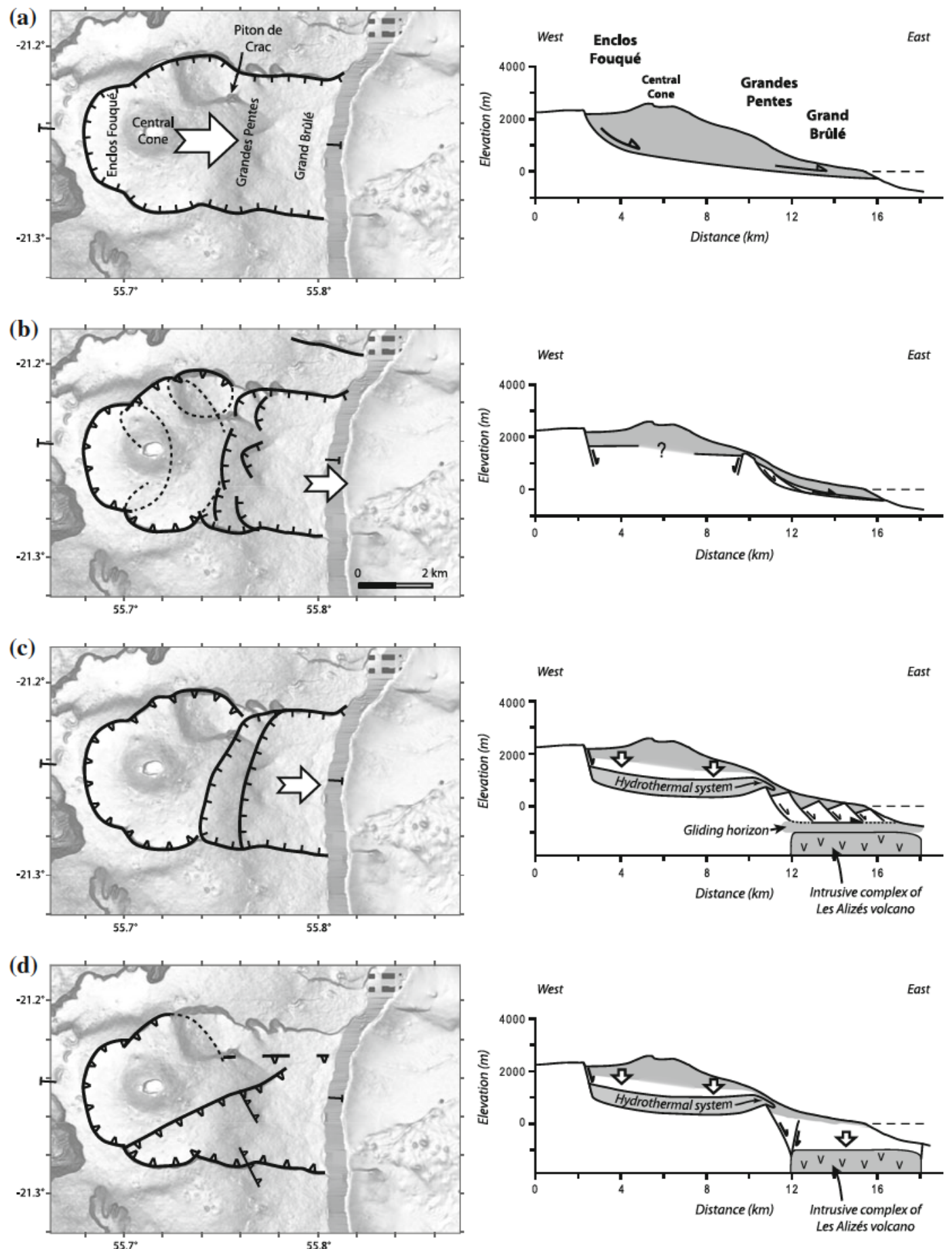

Collapse caldera and normal faults

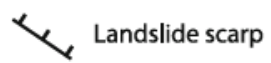

Fig. 4.4 Interpretations of the formation of the U-shaped structure composed of the Enclos Fouqué, the Grandes Pentes and the Grand Brûlé areas. a Duffield et al. (1982),
Gillot et al. (1994), Labazuy (1996), Oelher et al. (2004, 2008). b Bachèlery (1981). c Merle and Lénat (2003). d Michon and Saint-Ange (2008) 
Duffield et al. 1982; Gillot et al. 1994; Oehler et al. 2004, 2008), or the deformation of the hydrothermal system in a way similar to the one proposed for the Enclos Fouqué (Fig. 4.5d; Merle and Lénat 2003). The massive debris avalanche deposits on the submarine flank containing blocks dated between 110 and 45 ka suggests that a large volcano destabilization is compatible with the development of the Plaine des Sables scarp (Labazuy 1996).

Geological data suggest the occurrence of older collapse structures related to the Ancient Piton de la Fournaise, i.e. older than $60 \mathrm{ka}$. However, except for the Morne Langevin caldera whose western limit is well defined, the existence, the type (vertical or lateral collapses) and the limits of the other structures are still poorly constrained (Oehler et al. 2008; Merle et al. 2010). The atypical orientation of the Rivière des Remparts canyon, almost concentric instead of radial to the volcano's summit, would have been controlled by an initial landslide (Duffield et al.
1982; Gillot et al. 1994; Merle et al. 2010). After this event whose age is estimated at about $290 \mathrm{ka}$ ago, the Ancient Piton de la Fournaise would have experienced two successive caldera collapses at $\sim 250 \mathrm{ka}$ and $\sim 150 \mathrm{ka}$, corresponding to the Rivière des Remparts and Morne Langevin calderas, respectively (Bachèlery and Mairine 1990; Merle et al. 2010).

\subsubsection{Rift Zones}

On ocean basaltic volcanoes, magma transfer at shallow levels generally occurs along preferential intrusion paths named rift zones (e.g. MacDonald 1972). At the surface, volcanic rift zones are outlined by a concentration of pyroclastic cones and eruptive fissures that results from their overall history of activity. At depth, their existence is indicated by dense networks of subvertical intrusions (Walker 1986).

The distribution of the cinder cones built on the massif of Piton de la Fournaise suggests the
Fig. 4.5 Origin of the main volcano-tectonic structure of Piton de la Fournaise. a Summit collapse calderas and landslide of the lower eastem flank (Bachèlery 1981). b Successive huge landslides (Duffield et al. 1982; Gillot et al. 1994). c Successive huge landslides (Oehler et al. 2004, 2008). d Summit collapse calderas and landslides (Merle and Lénat 2003; Merle et al. 2010). PSS Plaine des Sables scarp. EF Enclos. $R F$ Ravine Ferdinand
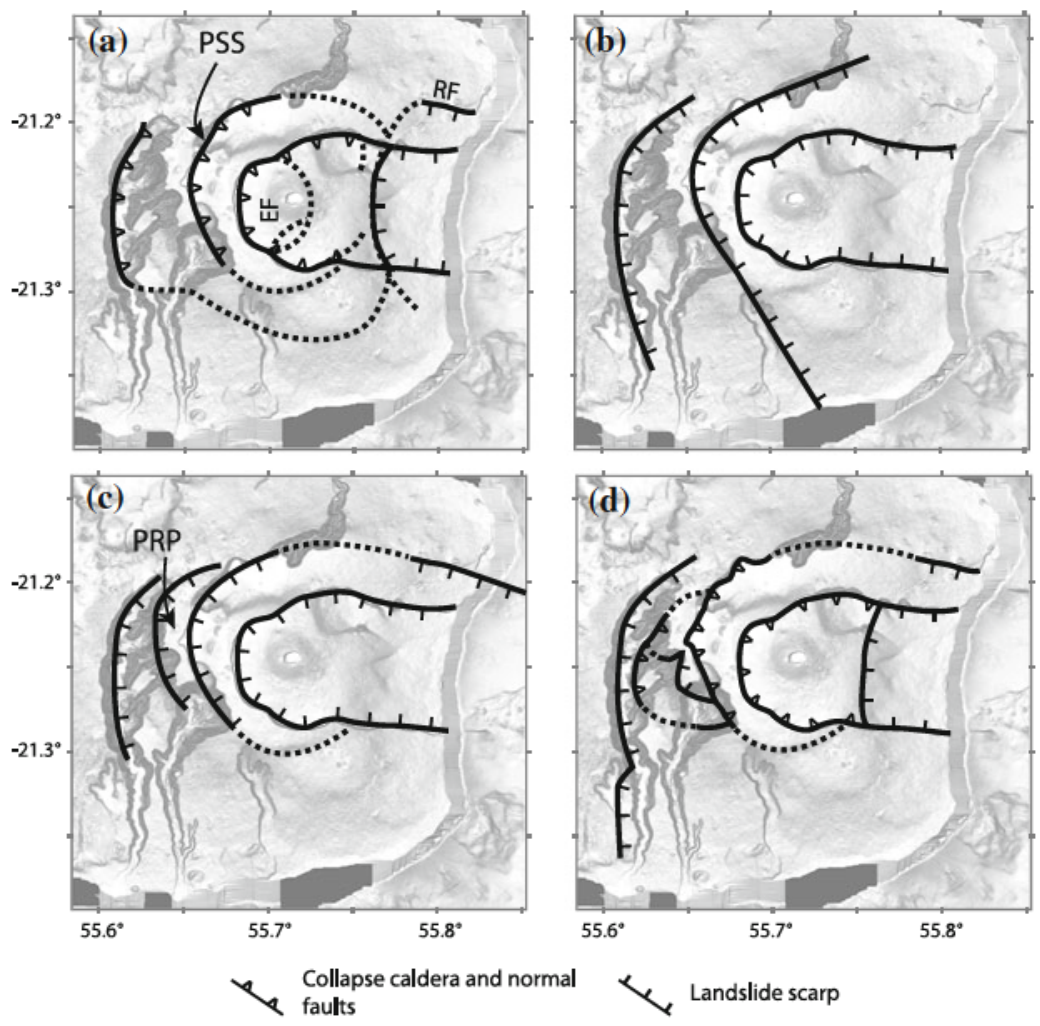
occurrence of two NE and SE rift zones (Fig. 4.2) and a NW-SE rift zone located between the Enclos Fouqué caldera and the summit of the Piton des Neiges inactive volcano (Bachèlery 1981; Chevallier and Bachèlery 1981; Villeneuve and Bachèlery 2006; Michon et al. 2016, this book for a review). The NE and SE rift zones are characterized by a smooth convex surface. Unlike the rift zones of the volcanoes of Hawaii, the average eruption frequency of Piton de la Fournaise rift zone is low for the historical period (post $1638 \mathrm{CE}$ ), with about one enuption every 50 years. This rate is even lower for the NW-SE rift zone for which radiocarbon data suggest eruptive occurrences of one event every 200 years (Morandi et al. 2016, this book, Chap. 8).

For the Ancient Piton de la Fournaise, which mostly crops out in the deeply incised Rivière des Remparts, Rivière Langevin and Rivière de l'Est, dyke distribution suggests the occurrence of a SW rift zone active between 530 and $290 \mathrm{ka}$ (Mairine and Bachèlery 1997). This rift zone also named the Ilet Edouard rift zone is composed of a dense network of dykes in the western scarp of the Rivière des Remparts (Fig. 4.2; Bachèlery and Mairine 1990).

\subsection{Geological Evolution}

After the pioneering works of Bachèlery (1981) and Chevalier and Bachèlery (1981) at the beginning of the 1980's, the old part of the massif has been studied by Bachèlery and Mairine (1990) and Mairine and Bachèlery (1997) and summarized by Bachèlery and Lénat (1993) in the 1990's. More recently, the geology of the Piton de la Fournaise has been revisited by Michon and Saint-Ange (2008) and Merle et al. (2010).

\subsubsection{The Ancient Piton de la Fournaise}

The oldest on-land outcrops are dated at about $530 \mathrm{ka}$ (Gillot and Nativel 1989) and have been grouped into a single Pintades lava unit (Bachèlery 1981; Bachèlery and Mairine 1990; Mairine and Bachèlery 1997; Merle et al. 2010), observed at the base of all lava sequences in the deep valleys incising Piton de la Fournaise (Rivière des Remparts, Rivière de l'Est and Rivière Langevin). According to recent interpretations (Smietana 2011), the Pintades lava unit, composed of feldspar-rich basalt to mugearite, does not belong to the Piton de la Fournaise series since it includes differentiated rocks, more alkalic in bulk composition than typical Piton de la Fournaise lavas (Albarède et al. 1997; Luais 2004). Instead, it would be considered as the upper part of its basement, possibly related to the old Les Alizés volcano according to Merle et al. (2010). Yet, such an interpretation does not take into account the radial distribution of the dykes intruded during this period, which suggests a volcanic centre around the Plaine des Sables, i.e. the locus of the ancient Piton de la Fournaise (Bachèlery and Mairine 1990). Thus, whether the Pintades unit belongs to the Alizés volcano or corresponds to an initial alkalic phase of Piton de la Fournaise is still debated. The magma composition changed at around $400 \mathrm{ka}$ when the Pintades unit was overlain by the basaltic Olivine Lavas unit (Luais et al. 2004; Merle et al. 2010). The numerous dykes cropping out in the Rivière des Remparts and Rivière Langevin exhibit a radial distribution similar to that of the Pintades unit, suggesting a similar location of the volcanic centre during both phases. Morphological reconstructions determined from the remnant massif built during this period, west of the Rivière des Remparts, suggest that the edifice had reached an elevation of around $2700 \mathrm{~m}$ asl (Gayer et al. 2014). Note that Chevallier and Bachèlery (1981) proposed two coeval volcanic centres for this old phase, one located north of the Plaine des Sables and the other one close to the current location of the summit of Piton de la Fournaise. The Ancient Piton de la Fournaise then experienced alternating episodes of volcanic destruction and reconstruction, destructive episodes of the edifice being characterised by giant landslides and summit caldera collapses (Merle et al. 2010) (Fig. 4.5). 
The oldest recognized landslide occurred at about $290 \mathrm{ka}$. This landslide resulted in the systematic stripping of the Olivine Lavas unit over a large area from the Rivière des Remparts to the Rivière Langevin canyons. At about $250 \mathrm{ka}$, a first caldera collapse forming the $8.5-\mathrm{km}$-wide Rivière des Remparts caldera would have affected the volcano (Merle et al. 2010). This event was followed by the development of the Mahavel volcano whose deposits correspond to (1) west dipping interstratified scoria and lava flows in the Bras de Mahavel, tentatively interpreted as evidencing the building of a main scoria cone at this time (Bachèlery and Mairine 1990), and (2) a pile of regular lava flows with a gentle dip toward the south that form the base on the Grand Coude plateau (Fig. 4.2). The Mahavel volcano was then cut at around $150 \mathrm{ka}$ by the second recognised caldera collapse of Piton de la Fournaise. Unlike the Rivière des Remparts caldera, the western limit of this collapse structure, named the Morne Langevin caldera after Bachèlery and Mairine (1990), is well visible in the scarps of the Rivière des Remparts (see Fig. 4.4a in Merle et al. 2010). It bounds to the south and to the west the Plaine des Remparts plateau (Fig. 4.5). This caldera was entirely filled around $80-100$ ka ago by a $>200$-m-thick series of thick lava units that flowed over the western caldera scarps. Lava flows invaded a paleo-depression located between the current course of the Rivière des Remparts and the Rivière Langevin, which was resulting either from erosion (Bachèlery and Mairine 1990; Mairine and Bachèlery 1997) or from a southward directed landslide (Merle et al. 2010). Whatever the origin of this depression, geochronological dating indicates that the Ancient Piton de la Fournaise constitutes the basement of the modern one east of the Rivière Basse Vallée (Gillot and Nativel 1989; Gillot et al. 1994) (Fig. 4.2).

Finally, the evolution of the Ancient Piton de la Fournaise indicates that after each event of caldera collapse, the lava flows remained initially confined to the caldera depression, allowing deep canyons to be eroded on the external slopes of the volcano. These canyons were later filled up when lavas finally overflowed the caldera rim and were able to flow down the external slopes. This excavating/infilling process occurred twice after the formation of the Rivière des Remparts and Morne Langevin calderas (Merle et al. 2010).

\subsubsection{The Recent Shield of Piton de la Fournaise}

For the Recent Shield, the main eruptive centre was located at the same place of the today's Central Cone, but Letourneur et al. (2008) suggest the possibility of the occurrence of an intermediate location before activity attained the present one. The age of the eastward migration of the eruptive centre remains controversial, as no decisive arguments have been found for an indisputable chronology (Merle et al. 2010). Bachèlery and Mairine (1990) propose that the eastward migration could have taken place at about $150 \mathrm{ka}$, concurrently with the formation of the Morne Langevin caldera. A second possibility is that it occurred after the Plaine des Sables caldera formed at about 65 and/or $40 \mathrm{ka}$ (Bachèlery and Mairine 1990; Gillot and Nativel 1989; Merle et al. 2010; Staudacher and Allègre 1993).

A new edifice built east of the ancient volcanic centre after the collapse of the Plaine des Sables. The formation of the most recent $8 \mathrm{~km}$-wide caldera, termed the Enclos Fouqué caldera, stopped its activity. This event marked the most recent major volcano-tectonic event in the history of Piton de la Fournaise whose timing and dynamics remains unclear (see discussion in Sect. 4.3.1). Caldera formation has been initially associated with the emplacement of the Bellecombe Ash Member, a sequence of ash deposits cropping along the western area of the Enclos Fouqué caldera (Bachèlery 1981; MohamedAbchir 1996; Ort et al. 2014). An age of $4745 \pm 130 \mathrm{yr}$ BP is usually assumed as an older limit for this caldera collapse event and the beginning of the Bellecombe paroxysmal explosive events (Mohamed-Abchir 1996; Staudacher and Allègre 1993). This age corresponds to a radiocarbon dating of the uppermost lava flows of the Bellecombe scarp (Bachèlery 1981). 
Two ages are available for the lowermost ashes of the Bellecombe sequence, one in a gully inside the Plaine des Sables $(4175 \pm 145$ yr BP; Mohamed-Abchir 1996) and another on the Langevin cliff ( $4880 \pm 35$ yr BP; Morandi et al. 2016, this book, Chap. 8). This age range is broadly consistent with that provided by cosmogenic dating, which indicate ages older than $3340 \pm 1012 \mathrm{yr}$ for the lava flows constituting the lavas topping the western rim of Enclos Fouqué caldera (Staudacher and Allègre 1993). However, the recent reappraisal of the existing radiocarbon data, enriched by new dating, suggests that Bellecombe ashes groups several explosive events, whose age ranges between $4880 \pm 35 \mathrm{yr}$ BP and $2340 \pm 30$ yr BP (Morandi et al. 2016, this book, Chap. 8).

Whatever the origin and the age of the depression formed by the Grandes Pentes and the Grand Brûlé, the U-shaped structure bounds most of the recent volcanic activity (Villeneuve and Bachèlery 2006; Michon et al. 2013) and plays a key role in the current sedimentation on the submarine slopes (Ollier et al. 1998; Saint-Ange et al. 2013).

The concentration of volcanic activity in the upper part of the caldera led to the construction of the 400-m-high steep Central Cone inside the Enclos Fouqué (Fig. 4.2). Its internal structure has been partially exposed down to about $350 \mathrm{~m}$ below the summit by the 2007 caldera collapse (Fig. 4.6). Five main types of units have been recognized: piles of thin lava flows, a few and thin tephra beds, pit crater infills, intrusive bodies and localized hydrothermal haloes (Peltier et al. 2012; Michon et al. 2013). A large portion of the $\mathrm{N}, \mathrm{E}$ and SE caldera walls exposes uniform piles of thin lava flows (Fig. 4.6a). In two areas, accumulations of thick horizontal lava flows have been interpreted as infilling of summit pit craters. To the south, a 150-200-m-diameter filled crater, initially named Dolomieu (Bory de Saint-Vincent 1804) likely formed during the 1791 large eruption (Peltier et al. 2012; Michon et al. 2013). To the west, a much larger pit crater, the Pre-Bory pit crater, with an estimated diameter of about $800 \mathrm{~m}$, cut the pile of thin lava flows forming most of the volcano upper part
(Fig. 4.6b). Its vertical extent is greater that the $200 \mathrm{~m}$ exposed in the wall. A dense network of subvertical dykes, generally less than one meter in width, is observed in the walls of the Dolomieu summit caldera, more specifically in the $\mathrm{N}$, SW and SE scarps. The sectors of highest concentration of dykes correspond to the proximal zone of the summit N25-30 and N120 rift (Michon et al. 2013, 2016, this book, Chap. 7).

A recent reappraisal of historical reports combined with new geological observations suggests that the historical activity of the Central Cone was characterized by a lava lake activity centred on the current inactive Bory crater (Michon et al. 2013). This lava lake fed the largest recent pahoehoe lava field, the Enclos Fouqué lava field (named CLEF in Lénat et al. 2001b), between 1733 and $1750 \mathrm{CE}$. The volcanic activity then shifted to the eastern part of the volcano summit with the development of a long-lasting summit eruption focused on the Mamelon Central, which ended with the large 1791 explosive eruption. A new lava lake was observed in 1841 in the eastern part of the current Dolomieu crater (Maillard 1862). Again, this summit activity continued until the 1860 paroxysmal explosive eruption (Michon et al. 2013). Since then, Piton de la Fournaise entered a phase of frequent, short-lived eruptions where pit crater collapses recurrently affected the Dolomieu crater.

The 2007 caldera collapse has led several authors (Michon et al. 2007; Gailler et al. 2009; Peltier et al. 2009; Staudacher et al. 2009; Lénat et al. 2012) to suggest that, as a consequence of the subsidence, a cylinder of faulted and fractured rocks must exist between the surface and the top of the magma reservoir. Indeed, the interpretations of the geophysical and visual observations during the collapse converge toward a model of a piston-like subsidence in one or several magma pockets being emptied by a voluminous lateral eruption. Lénat et al. (2012), noting that episodes of collapse are recurrent in the summit area in historical times, infer that the collapse column constitutes a major lithological heterogeneity with a significantly lower strength and higher permeability than that of the surrounding rocks. 
(a)

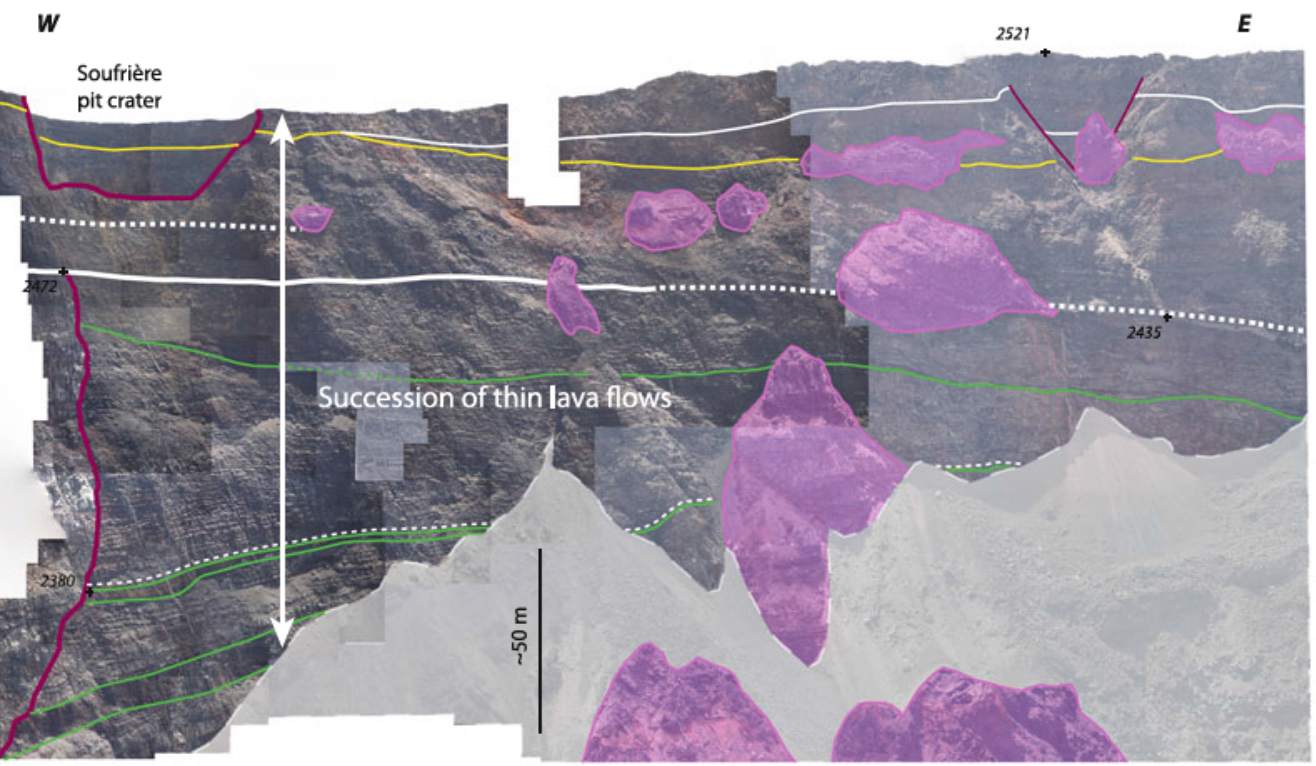

(b)

SW

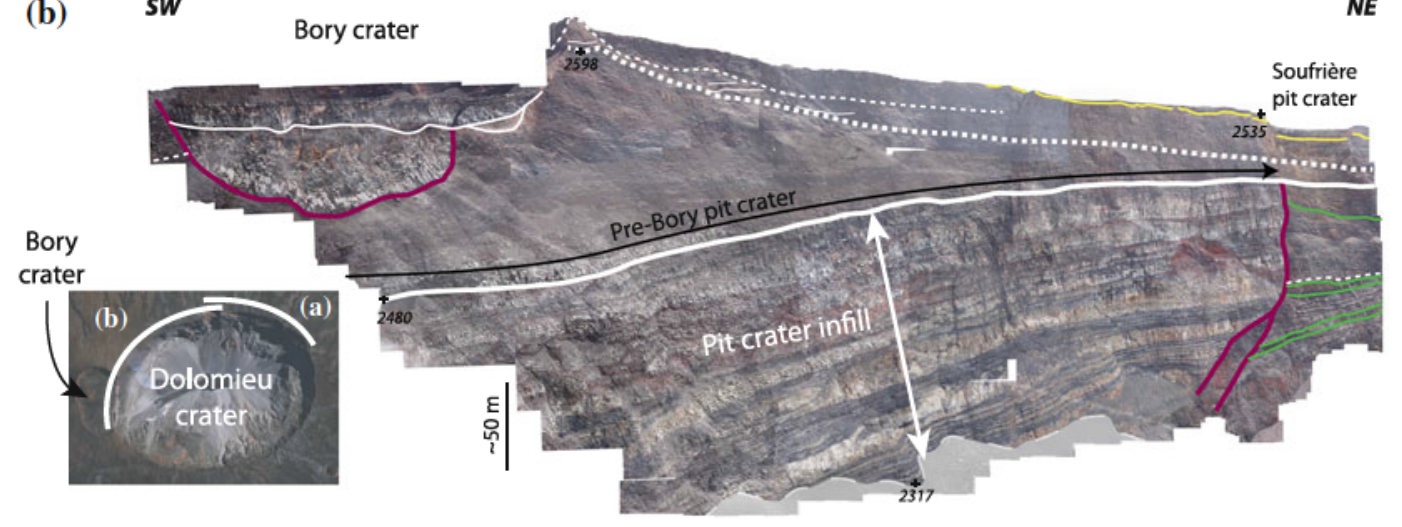

Fig. 4.6 Inner structure of the Central Cone exposed in the Enclos Fouqué summit caldera (modified after Michon et al. 2013). The 2007 caldera walls reveal that the central cone is mostly built by thin lava flows (a). The cone experienced a large pit crater collapse (Pre-Bory), which was subsequently filled by thick lava units (b). Purple

\subsection{Synthesis}

This review on the geology and morphostructural evolution of Piton de la Fournaise summarizes the intense debate that exists since the 80 's to explain the origin of the main volcano-tectonic structures. Concerning the collapse structures, most of the controversies are focused on the involved processes, i.e., collapse calderas versus lines Boundaries of collapse structures. White lines limits of the main litho-stratigraphical units. Green and yellow lines secondary units. Pink slide blocks and remaining terraces. Grey screes and talus. Selected point elevations are shown in metres

lateral landslides. A second and major issue is the timing and dynamics of caldera formation and its link with explosive phreatomagmatic activity like the one recorded in Bellecombe ashes. Another critical point resides in the location of the emission centre for the old alkaline series forming the base of the Piton de la Fournaise volcano. Do these plagioclase-rich early lavas correspond to the final activity of the oldest volcano forming $\mathrm{La}$ Réunion (Les Alizés volcano) or to an initial 
phase of Piton de la Fournaise? Indubitably, further works are required to potentially answer these issues, lateral versus vertical collapse and shift of the magma composition, which are shared with other volcanoes worldwide.

\section{References}

Albarède F, Luais B, Fitton G, Semet M, Kaminski E, Upton BGJ, Bachèlery P, Cheminée JL (1997) The geochemical regimes of Piton de la Fournaise volcano (Réunion) during the last 530,000 years. J Petrol 38:171-201

Babonneau N, Delacourt C, Cancouët R, Sisavath E, Bachèlery P, Mazuel A, Jorry SJ, Deschamps A, Ammann J, Villeneuve N(2013) Direct sediment transfer from land to deep-sea: insights from new shallow-marine multibeam data at La Réunion Island. Mar Geol 346: 47-57. doi:10.1016/j.margeo.2013.08.006

Babonneau N, Villeneuve N, Mazuel A, Bachèlery $\mathrm{P}$ (2016) Erosion and volcaniclastic sedimentation at Piton de la Fournaise: from source to deep marine environment. In: Bachèlery P, Lénat JF, Di Muro A, Michon L (eds) Active volcanoes of the Southwest Indian Ocean: Piton de la Fournaise and Karthala. Active Volcanoes of the World. Springer, Berlin

Bachèlery P (1981) Le Piton de la Foumaise (lle de la Réunion). Etude volcanologique, structurale et pétrologique. PhD thesis 215 pp., Univ Clermont-Ferrand II, Clermont-Ferrand

Bachèlery P, Lénat JF (1993) Le Piton de la Fournaise. Mémoires de la Société Géologique de France. Nouvelle Série 163:221-229

Bachèlery P, Mairine P (1990) Evolution volcanostructurale du Piton de la Fournaise depuis $0.53 \mathrm{Ma}$. In: Lénat JF (ed) Le volcanisme de la RéunionMonographie. Centre de Recherche en Volcanologie. Clermont-Ferrand, pp 213-242

Bachèlery P, Villeneuve N (2013) Hot spots and large igneous provinces.In: Shroder J, Owen L (eds) Treatise on geomorphology. Academic Press, San Diego, 5, pp 193-233

Bory de Saint-Vincent JBG (1804) Voyage dans les quatre principales iles des mers d'Afrique, fait par ordre du gouvernement, pendant les années neuf et dix de la République (1801 et 1802). Buisson (4 volumes)

Chevallier L, Bachèlery P (1981) Evolution structurale du volcan actif du Piton de la Fournaise, Ile de la Réunion -Océan indien occidental. Bull Volcanol 44:723-741

Cochonat P, Lénat JF, Bachèlery P, Boivin P, Cornaglia B, Deniel C, Labazuy P, Ledrezen E, Lipman P, Ollier G, Savoye B, Vincent P, Voisset M (1990) Gravity events as a primary process in the construction of a submarine volcano-sedimentary system (Fournaise volcano, Reunion Island). C. Rendus Acad Sci Serie II 311:679-686
Duffield WA, Stieltjes L, Varet J (1982) Huge landslide blocks in the growth of Piton de la Fournaise, La Reunion, and Kilauea Volcano, Hawaii. J Volcanol Geoth Res 12:147-160

Gailler LS, Lénat JF (2010) Three-dimensional structure of the submarine flanks of La Réunion inferred from geophysical data. J Geophys Res 115(B12). doi: 10. 1029/2009JB007193

Gailler L, Lénat JF, Lambert M, Levieux G, Villeneuve N, Froger JL (2009) Gravity structure of Piton de la Fournaise volcano and inferred mass transfer during the 2007 crisis. J Volcanol Geotherm Res 184:31-48. doi:10.1016/j.jvolgeores.2009.01.024

Garcin M, Poisson B, Pouget R (2005) High rates of geomorphological processes in a tropical area: the Remparts River case study (Réunion Island, Indian Ocean). Geomorphology 67:335-350. doi:10.1016/j. geomorph.2004.11.002

Gayer E, Lopez P, Michon L (2014) DEM-based model for reconstructing volcano's morphology from primary volcanic landforms. Geophys Res Abstracts 16: EGU2014-10701

Gillot PY, Nativel P (1989) Eruptive history of the Piton de la Foumaise volcano, Réunion Island, Indian Ocean. J Volcanol Geotherm Res 36:53-65

Gillot PY, Lefèvre JC, Nativel PE (1994) Model for the structural evolution of the volcanoes of Réunion Island. Earth Planet Sci Lett 122:291-302

Hürlimann M, Marti J, Ledesma A (2004) Morphological and geological aspects related to large slope failures on oceanic islands: the huge La Orotava landslides on Tenerife, Canary Islands. Geomorphology 62:143-158

Labazuy P (1996) Recurrent landslides events on the submarine flank of Piton de la Fournaise volcano (Réunion Island). In: McGuire WJ, Jones AP, Neuberg $\mathrm{J}$ (eds) Volcano instability on the earth and other planets. vol 110, Geol Soc Spec Publ, pp 293-30

Le Friant A, Lebas E, Clément V, Boudon G, Deplus C, de Voogd B, Bachèlery P (2011) A new model for the evolution of $\mathrm{La}$ Réunion volcanic complex from complete marine geophysical surveys. Geophys Res Lett 38:L09312. doi:10.1029/2011GL047489

Lénat J, Gibert-Malengreau B, Galdeano A (2001a) A new model for the evolution of the volcanic island of Reunion (Indian Ocean). J Geoph Res-Solid Earth 106:8645-8663

Lénat JF, Bachèlery P, Desmulier F (2001b) Genèse du champ de lave de l'Enclos Fouqué; une éruption d'envergure exceptionnelle du Piton de la Fournaise (Réunion) au 18ème siècle. Bull Soc géol Fr 172:177-188

Lénat JF, Boivin P, Deniel C, Gillot PY, Bachèlery P (2009) Age and nature of deposits on the submarine flanks of Piton de la Fournaise (Reunion Island). J Volcanol Geotherm Res 184:199-207. doi:10.1016/ j.jvolgeores.2009.01.013

Lénat JF, Bachèlery P, Peltier A (2012a) The interplay between collapse structures, hydrothermal systems and magma intrusions: the case of the central area of Piton de la Fournaise volcano. Bull Volc 7:407-421. doi:10.1007/s00445-011-0535-3 
Lénat JF, Bachèlery P, Merle O (2012b) Anatomy of Piton de la Fournaise volcano (La Réunion, Indian Ocean). Bull Volcanol 74:1945-1961. doi:10.1007/ s00445-012-0640-y

Lénat JF, Vincent PM, Bachèlery P (1989) The off-shore continuation of an active basaltic volcano: Piton de la Fournaise (Réunion Island, Indian Ocean); structural and geomorphological interpretation from sea beam mapping. J Volcanol Geoth Res 36:1-36.

Letoumeur L, Peltier A, Staudacher T, Gudmundsson A (2008) The effects of rock heterogeneities on dyke paths and asymmetric grounddeformation: the example of Piton de la Fournaise (Réunion Island). J Volcanol Geotherm Res 173:289-302

Luais B (2004) Temporal changes in $\mathrm{Nd}$ isotopic composition of Piton de la Fournaise magmatism (Reunion Island, Indian Ocean). Geochem Geophys Geosyst 5:Q01008. doi:10.1029/2002GC000502

MacDonald GA (1972) Volcanoes. Prentice-Hall, Englewood Cliffs 510 pp

Maillard L (1862) Notes sur l'île de la Réunion (Bourbon). Lanée, Paris 344 pp

Mairine P, Bachèlery P (1997) Un grand épisode érosionnel dans l'histoire ancienne du Piton de la Fournaise. C Rendus Acad Sci Paris 325:243-249

Malahoff A (1987) Geology of the summit of Loihi submarine volcano. US Geol Surv Prof Paper 1350:133-144

Mark RK, Moore J (1987) Slopes of the Hawaiian ridge. US Geol Surv Prof Pap 1350:101-107

Merle O, Borgia A (1996) Scaled experiments of volcanic spreading. J Geophys Res 101:13805-13817

Merle O, Lénat J (2003) Hybrid collapse mechanism at Piton de la Foumaise volcano, Reunion Island, Indian Ocean. J Geophys Res-Solid Earth 108(B3):2166. doi: 10.1029/2002JB002014

Merle O, Mairine P, Michon L, Bachèlery P, Smietana M (2010) Calderas, landslides and paleo-canyons on Piton de la Fournaise volcano (La Réunion Island, Indian Ocean). J Volcanol Geotherm Res 189:131142. doi:10.1016/j.jvolgeores.2009.11.001

Michon L, Saint-Ange F (2008) Morphology of Piton de la Fournaise basaltic shield volcano (La Réunion Island): characterization and implication in the volcano evolution. J Geophys Res-Solid Earth 113: B03203. doi: 10.1029/2005JB004118

Michon L, Staudacher T, Ferrazzini V, Bachelery P, Marti J (2007) April 2007 collapse of Piton de la Fournaise: a new example of caldera formation. Geophys Res Lett 34:L21301. doi:10.1029/2007GL031248

Michon L, Di Muro A, Villeneuve N, Saint-Marc C, Fadda P, Manta F (2013) Explosive activity of the summit cone of Piton de la Fournaise volcano (La Réunion island): a historical and geological review. J Volcanol Geotherm Res 264:117-133. doi:10.1016/ j.jvolgeores.2013.06.012

Michon L, Ferrazzini V, Di Muro A (2016) Magma paths at Piton de la Fournaise volcano. In: Bachèlery P, Lénat JF, Di Muro A, Michon L (eds) Active volcanoes of the Southwest Indian Ocean: Piton de la Fournaise and Karthala. Active Volcanoes of the World. Springer, Berlin

Mohamed-Abchir A (1996) Les Cendres de Bellecombe: un évènement majeur dans le passé récent du Piton de la Fournaise, Ile de la Réunion. PhD thesis, Univ Paris VII 248 pp

Moore JG (1964) Giant submarine landslides on the Hawaiian ridge. US Geol Surv Prof Pap 501:D95-D98

Moore JG, Mark MK (1992) Morphology of the Island of Hawaii. GSA Today 2:257-262

Morandi A, Di Muro A, Principe C, Michon L, Leroi G, Norelli F, Bachèlery P (2016) Pre-historic explosive activity at Piton de la Fournaise volcano. In: Bachèlery P, Lénat JF, Di Muro A, Michon L (eds) Active volcanoes of the Southwest Indian Ocean: Piton de la Fournaise and Karthala. Active Volcanoes of the World. Springer, Berlin

Oehler JF, Labazuy P, Lénat JF (2004) Recurrence of major flank landslides during the last 2-Ma-history of Reunion Island. Bull Volcanol 66:585-598. doi:10. 1007/s00445-004-0341-2

Oehler JF, Lénat JF, Labazuy P (2008) Growth and collapse of the Reunion Island volcanoes. Bull Volcanol 70:717-742. doi:10.1007/s00445-007-0163-0

Ollier G, Cochonat P, Lénat JF, Labazuy P (1998) Deep-sea volcaniclastic sedimentary systems: an example from La Foumaise volcano, Reunion Island, Indian Ocean. Sedimentology 45:293-330

Ort M, Di Muro A, Michon L, Bachèlery P (2014) The Bellecombe ash: indications of explosive eruptions at Piton de la Fournaise, Reunion Island. IAVCEI 5IMC conference. Queretaro, Mexico

Peltier A, Staudacher T, Bachèlery P, Cayol V (2009) Formation of the April 2007 caldera collapse at Piton de La Fournaise volcano: Insights from GPS data. J Volcanol Geotherm Res 184:152-163. doi:10.1016/ j.jvolgeores.2008.09.009

Peltier A, Massin F, Bachèlery P, Finizola A (2012) Insights on internal structures and edification of basaltic shield volcanoes: new field investigations on Piton de La Foumaise. Bull Volc 74:1881-1897. doi:10.1007/s00445-012-0636-7

Rowland SK (1996) Slopes, lava flow volumes, and vent distributions on Volcan Fernandina, Galapagos Islands. J Geophys Res 101:27657-27672

Rowland S, Garbeil H (2000) Slopes of oceanic basalt volcanoes. In: Mouginis-Mark PJ, Crisp JA, Fink JH (eds) Remote sensing of active volcanism. AGU Geophys Monogr Ser 116, pp 223-247

Saint-Ange F, Savoye B, Michon L, Bachèlery P, Deplus C, de Voogd B, Dyment J, Le Drezen E, Voisset M, Le Friant A, Boudon G (2011) A volcaniclastic deep-sea fan off $\mathrm{La}$ Réunion Island (Indian Ocean): gradualism versus catastrophism. Geology 39:271-274. doi:10.1130/g31478.1

Saint-Ange F, Bachèlery P, Babonneau N, Michon L, Jorry S (2013) Volcaniclastic sedimentation on the submarine slopes of a basaltic hotspot volcano: Piton de la Foumaise volcano (La Réunion Island, Indian Ocean). Mar Geol 337:35-52. doi:10.1016/j.margeo. 2013.01.004 
Sisavath E, Babonneau N, Saint-Ange F, Bachèlery P, Jorry S, Deplus C, de Voogd B, Savoye B (2011) Morphology and sedimentary architecture of a modern volcaniclastic turbidite system: the Cilaos fan, offshore La Réunion Island. Mar Geol 288:1-17. doi:10.1016/j. margeo.2011.06.011

Sisavath E, Mazuel A, Jorry S, Babonneau N, Bachèlery P, de Voogd B, Salpin M, Emmanuel L, Beaufort L, Toucanne S (2012) Processes controlling a volcaniclastic turbiditic system during the last climatic cycle: example of the Cilaos deep-sea fan, offshore La Reunion Island. Sedim Geol 281:180-193. doi:10. 1016/j.sedgeo.2012.09.010

Smietana M (2011) Pétrologie, géochronologie (K-Ar) et géochimie élémentaire et isotopique $(\mathrm{Sr}, \mathrm{Nd}, \mathrm{Hf}, \mathrm{Pb})$ de laves anciennes de La Réunion: Implications sur la construction de l'édifice volcanique. Unpublished PhD thesis, Univ. La Réunion pp. 364

Staudacher T, Allègre CJ (1993) Ages of the second caldera of Piton de la Fournaise volcano (Réunion) determined by cosmic ray produced ${ }^{3} \mathrm{He}$ and ${ }^{21} \mathrm{Ne}$. Earth Planet Sci Lett 119:395-404

Staudacher T, Ferrazzini V, Peltier A, Kowalski P, Boissier P, Catherine P, Lauret F, Massin F (2009) The April 2007 eruption and the Dolomieu crater collapse, two major events at Piton de la Foumaise (La Réunion Island, Indian Ocean). J Volcanol Geotherm Res 184:126-137. doi:10.1016/j.jvolgeores.2008.11.005

Tort A, Finizola A (2005) Structural survey of misti volcanic cone (southern Peru) combining elliptical fourier function analysis of the volcano morphology and self-potential measurements. J Volcanol Geotherm Res 141:283-297

Villeneuve N, Bachèlery P (2006) Revue de la typologie des éruptions au Piton de La Fournaise, processus et risques volcaniques associés. Cybergeo Eur J Geog (http://cybergeo.revues.org/2536)

Walker GPL (1986) Koolau dike complex, Oahu: intensity and origin of a sheeted-dike complex high in a Hawaiian volcanic edifice. Geology 14:310-313 